Павелко О. В., к.е.н., доцент (Національний університет водного господарства та природокористування, м. Рівне)

\title{
КОНЦЕПТУАЛЬНІ ЗАСАДИ ПОБУДОВИ ОБЛІКУ ФІНАНСОВИХ РЕЗУЛЬТАТІВ БУДІВЕЛЬНИХ ПІДПРИЕМСТВ
}

У статті досліджено рівні управління фінансовими результатами у будівництві. Їх виокремлено з позиції мікро- та макроекономіки. Систематизовано основні нормативно-правові документи, що регулюють базові засади здійснення будівництва та обліку його фінансових результатів. Проаналізовано кількість підприємств, які займаються будівництвом з розподілом на великі, середні, малі та мікропідприємства. Окреслено законодавчо встановлені вимоги до будівельних підприємств, які становлять суспільний інтерес. Ключові слова: будівництво, облік, будівельне підприємство, методологія обліку, вид економічної діяльності, фінансові результати, звітність, будівельна продукція.

Актуальність теми. Будівництво як один із пріоритетних видів економічної діяльності чинить вагомий вплив на розвиток вітчизняної економіки, забезпечуючи інші галузі продукцією, без якої неможливе їх подальше ефективне функціонування. Значення капітальних інвестицій у будівництво впродовж останніх років мають тенденції до зменшення, проте у структурі капітальних інвестицій країни загалом вони є суттєвими (табл. 1).

Таблиця 1

Капітальні інвестиції за видами економічної діяльності

за 2010-2016 роки

\begin{tabular}{|l|c|c|c|c|c|c|c|}
\hline $\begin{array}{l}\text { Види економі- } \\
\text { чної діяльності }\end{array}$ & $\mathbf{2 0 1 0}$ & $\mathbf{2 0 1 1}$ & $\mathbf{2 0 1 2}$ & $\mathbf{2 0 1 3}$ & $\mathbf{2 0 1 4}$ & $\mathbf{2 0 1 5}$ & $\mathbf{2 0 1 6}$ \\
\hline $\begin{array}{l}\text { Усього, } \\
\text { Млн грн }\end{array}$ & 180575,5 & 241286 & 273256 & 249873,4 & 219419,9 & 273116,4 & 359216,1 \\
\hline Будівництво & 29767 & 31990,8 & 40760,3 & 40796,2 & 36056,7 & 43463,7 & 44444 \\
\hline У \% до всього & 16,5 & 13,3 & 14,9 & 16,3 & 16,4 & 15,9 & 12,4 \\
\hline
\end{tabular}

Кінцевою метою суб'єктів господарювання у будівництві $\epsilon$ нарощення значень позитивних фінансових результатів, управління якими уможливлюється за наявності належного інформаційного забезпечення, що слугує основою для посилення ролі бухгалтерського обліку.

Аналіз останніх досліджень і публікацій. 3 моменту введення в дію Закону України «Про бухгалтерський облік та фінансову звітність 
в Україні» від 16.07.1999 р. (зі змінами), прийняття П(С)БО 18 «Будівельні контракти», МСФЗ 15 «Дохід від договорів з клієнтами» (з введенням в дію якого будівельні підприємства, які складають звітність за міжнародними стандартами, у своїй діяльності не використовуватимуть надалі норми МСБО 11 «Будівельні контракти» та МСБО 18 «Дохід») опрацювання теоретико-практичних засад ведення обліку в будівництві спостерігається у численних публікаціях вітчизняних науковців, зокрема 3.-М.В. Задорожного [1; 2], М.В. Дерій [3], П.М. Кричуна [4], Я.Д. Крупки [2], Н.В. Мужевич [5], Л.І. Пославської [6], Т. М. Сороки [7], 0.І. Чижишин [8] та інших.

Незважаючи на суттєвий внесок вищеназваних вчених у розвиток базових аспектів обліку основної діяльності будівельних підприємств, значна частина праць за окресленою тематикою має вузькоспеціалізований характер: недостатньо грунтовно висвітлено питання рівнів управління фінансовими результатами у будівництві, малодослідженим залишається питання обліку будівельних підприємств, які становлять суспільний інтерес.

Постановка завдання. Мета дослідження полягає в формуванні рівнів управління фінансовими результатами в будівництві як кінцевої мети ефективного господарювання будівельних підприємств, ідентифікації рівнів основних нормативно-правових документів, що регулюють базові засади здійснення будівництва та обліку його фінансових результатів в Україні, висвітленні законодавчо встановлених вимог щодо ведення обліку та складання звітності до будівельних підприємств, які становлять суспільний інтерес.

Викладення основного матеріалу. В умовах сьогодення спостерігається чітка окреслена тенденція до зростання обсягів виконання будівельних робіт в Україні $(73726,9$ млн грн у 2016 р. проти 57515,0 млн грн 2015 р.), що потребує виважених та обґрунтованих методів управління, спрямованих на максимізацію фінансових результатів будівельних підприємств за одночасного зниження вартості об'єктів будівництва, що уможливлюється через скорочення обсягів витрат і зростання доходів від їх основної діяльності. У свою чергу, обсяги виконання будівельних робіт залежать від низки факторів (політичних, виробничих, екологічних, споживчих, інфраструктурноінвестиційних, фінансових, макроекономічних, соціальних, інноваційних) і через фінансові результати будівельних підприємств впливають на ВВП країни, що формується в умовах глобалізації, конкуренції, наявних ризиків, інституційних змін тощо (рис. 1). 

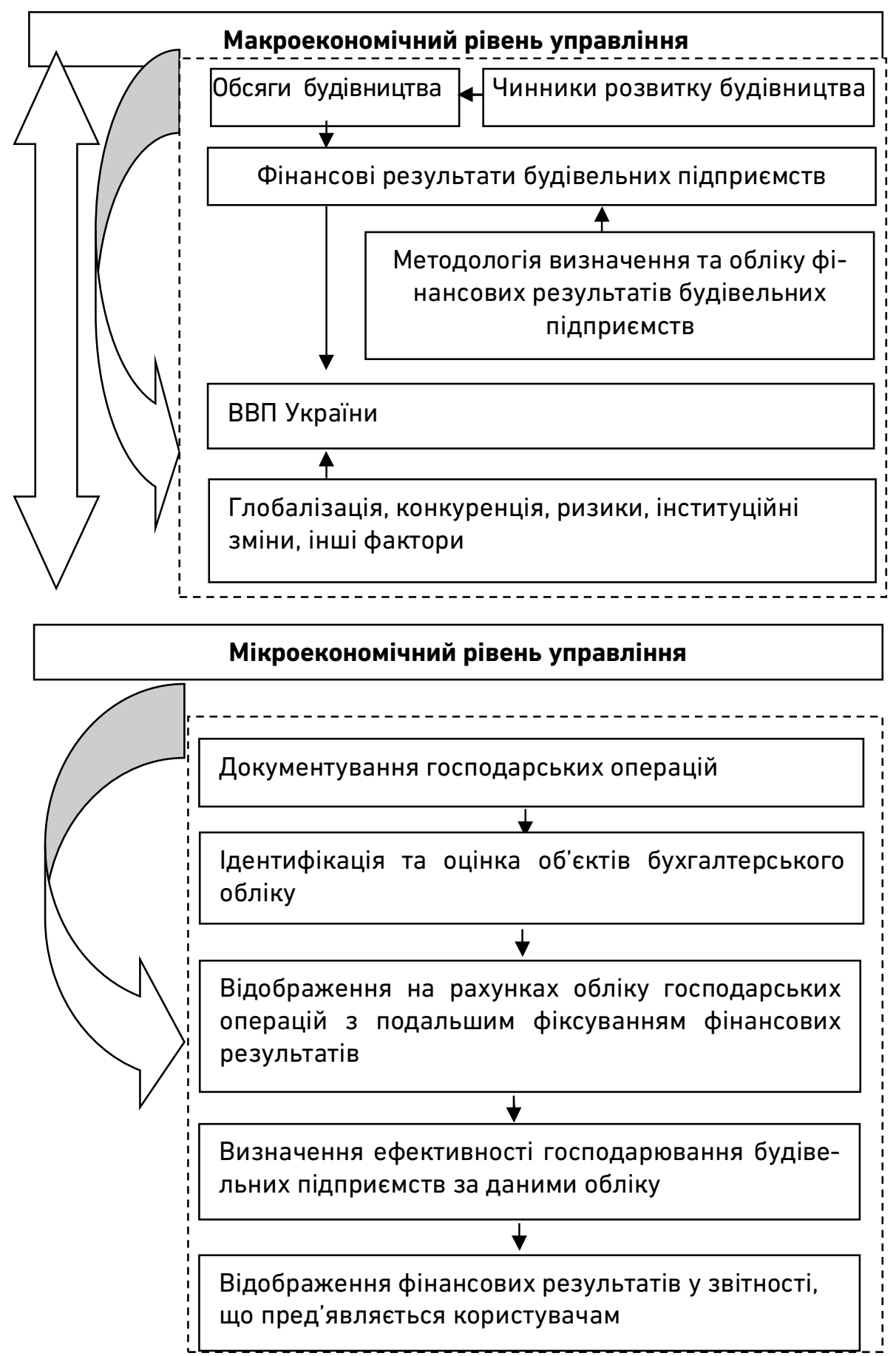

Рис. 1. Рівні управління фінансовими результатами у будівництві* *Розроблено автором

На фінансові результати будівельних підприємств чинить вплив і загальна методологія їх визначення та обліку, передбачена на за- 
конодавчому рівні.

Загальна методологія визначення та обліку фінансових результатів будівельних підприємств впливає на документування, ідентифікацію, оцінку об'єктів бухгалтерського обліку, відображення операцій на рахунках та в звітності, тобто на механізм формування й обліку фінансових результатів будівельних підприємств.

У дисертаційній роботі Чижишин 0.І. [8] окреслено господарський та фінансовий механізм як надбудови до механізму формування та обліку фінансових результатів будівельних підприємств, у структурі якого передбачено інституціональну ланку, функціональну ланку та нормативно-правову ланку. 3 нашої точки зору, доцільно було б також виокремити організаційно-економічний механізм будівельного підприємства, як сукупність організаційних і економічних важелів, які чинять вплив на систему управління підприємством, що сприяє отриманню конкурентних переваг та підвищенню результативності діяльності підприємства загалом.

До складу інституціональної ланки науковцем [8] включено фінансові органи і їх підрозділи (групи фінансових працівників), які безпосередньо здійснюють процес формування та обліку фінансових результатів діяльності. Функціональна ланка охоплює принципи організації та функціонування механізму, форми, методи, технології організації та реалізації фінансових відносин, стимули, санкції.

Нормативно-правова ланка - це система наказів, постанов, вказівок, положень, які регламентують застосування фінансових методів, важелів і стимулів, що визначають організаційну структуру, права, обов'язки, відповідальність, порядок роботи працівників бухгалтерії та інших економічних служб підприємства.

Саме нормативно-правове забезпечення, яким визначаються базові засади здійснення будівництва та обліку його фінансових результатів налічує досить значну кількість документів, положення яких часто суперечать одне одному, що ускладнює процес ведення обліку в цілому (рис. 2). Основні нормативно-правові документи, якими регламентовано базові засади здійснення будівництва та ведення обліку підприємствами, які функціонують в даному виді економічної діяльності, згруповано, при цьому виокремлено 6 рівнів управління: раїни;

- I рівень - фундамент усього законодавства - Конституція Ук-

- II рівень - кодекси України (Господарський, Цивільний, Податковий); 


\begin{tabular}{|c|c|}
\hline І рівень & Конституція України від 28.06.1996 № 254к/96-ВР \\
\hline $\begin{array}{l}\text { II pi- } \\
\text { вень }\end{array}$ & $\begin{array}{l}\text { - Господарський кодекс України від 16.01.2003 № 436-IV; } \\
\text { - Цивільний кодекс України від 16.01.2003 № 435-IV; } \\
\text { - Податковий кодекс України від 02.12.2010 № 2755-VI } \\
\end{array}$ \\
\hline $\begin{array}{l}\text { III } \\
\text { рівень }\end{array}$ & 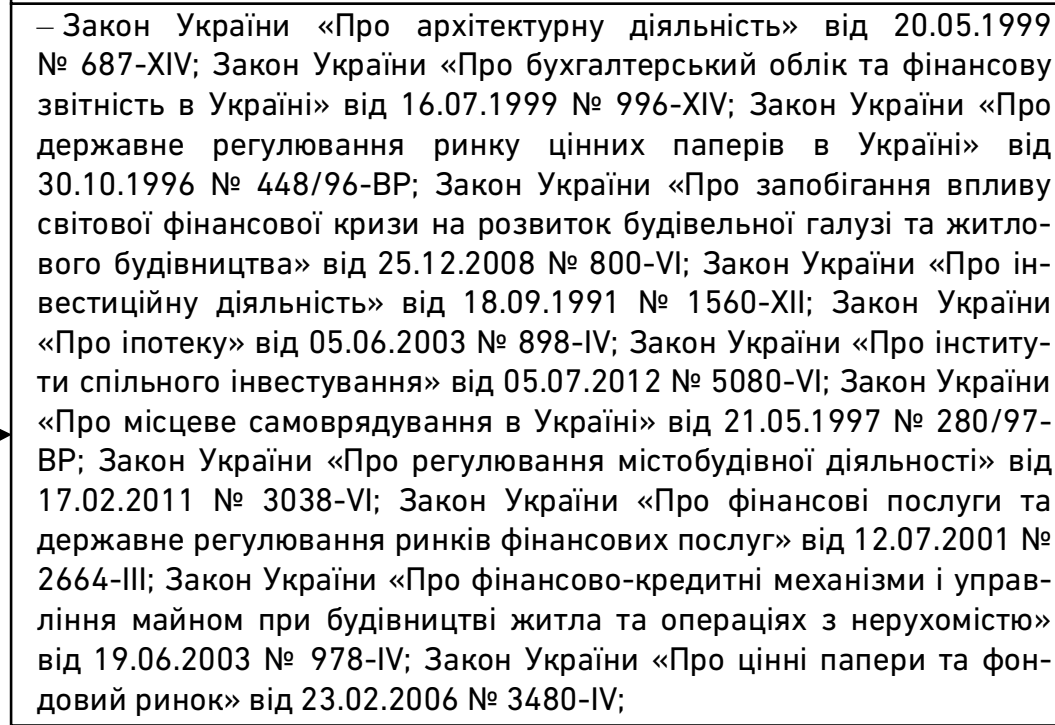 \\
\hline $\begin{array}{l}\text { IV } \\
\text { рівень }\end{array}$ & $\begin{array}{l}\text { - НП(С)БО } 1 \text { «Загальні вимоги до фінансової звітності» від } \\
\text { 07.02.2013 №73; } \\
\text { - П(С)БО } 16 \text { «Витрати» від 31.12.1999 № 318; } \\
\text { - П(С)БО } 18 \text { «Будівельні контракти» від 28.04.2001 № } 205\end{array}$ \\
\hline $\begin{array}{l}\text { V } \\
\text { рівень }\end{array}$ & $\begin{array}{l}\text { Методичні рекомендації з формування собівартості будівельно- } \\
\text { монтажних робіт від } 31.10 .2010 \text { № } 573 \text { (зі змінами) }\end{array}$ \\
\hline $\begin{array}{l}\text { VI } \\
\text { рівень }\end{array}$ & $\begin{array}{l}\text { - Правила визначення вартості будівництва «ДСТУ Б Д.1.1- } \\
\text { 1:2013 № } 293 \text { від 05.07.2013; } \\
\text { - Національний класифікатор України «Класифікація видів еко- } \\
\text { номічної діяльності ДК 009:2010» від 11.10.2010 № 457; } \\
\text { - Інструкція про застосування Плану рахунків бухгалтерського } \\
\text { обліку активів, капіталу, зобов'язань і господарських операцій } \\
\text { підприємств і організацій від 30.11.1999 № } 291\end{array}$ \\
\hline
\end{tabular}

Рис. 2. Основні нормативно-правові документи, що регулюють базові засади здійснення будівництва та обліку його фінансових результатів в Україні (згруповані за рівнями)* *Розроблено автором

- III рівень - закони України;

- IV рівень - П(С)БО (НП(С)БО 1, П(С)БО 16, П(С)БО 18);

- V рівень - Методичні рекомендації з формування собівартості будівельно-монтажних робіт від 31.10.2010 № 573 (зі змінами) (Правила визначення вартості будівництва «ДСТУ Б Д.1.1-1:2013 
№ 293 від 05.07.2013 р. тощо);

- VI рівень - інші документи (Правила визначення вартості будівництва «ДСТУ Б Д.1.1-1:2013 № 293 від 05.07.2013 тощо).

У будівництві активно функціонують як підприємства, так і фізичні особи-підприємці. За результатами 2016 р. кількість фізичнихосіб підприємців склала 25875 од. проти 24333 підприємств. Обсяг реалізованої продукції (товарів, послуг) суб'єктів господарювання за видами економічної діяльності представлено в табл. 2.

Таблиця 2

Обсяг реалізованої продукції (товарів, послуг) суб'єктів господарювання у 2016 р.*

\begin{tabular}{|c|c|c|c|c|c|}
\hline & \multirow{3}{*}{$\begin{array}{l}\text { Усього, } \\
\text { млн грн }\end{array}$} & \multicolumn{4}{|c|}{ У тому числі } \\
\hline & & \multicolumn{2}{|c|}{ підприємства } & \multicolumn{2}{|c|}{$\begin{array}{c}\text { фізичні } \\
\text { особи-підприємці }\end{array}$} \\
\hline & & $\begin{array}{l}\text { млн } \\
\text { грн }\end{array}$ & $\begin{array}{c}\text { у \% до за- } \\
\text { гальної кі- } \\
\text { лькості }\end{array}$ & $\begin{array}{l}\text { млн } \\
\text { грн }\end{array}$ & $\begin{array}{l}\text { у \% до за- } \\
\text { гальної кі- } \\
\text { лькості }\end{array}$ \\
\hline Усього, у т.ч.: & 6877077,3 & 6387872,7 & 100,0 & 489204,6 & 100,0 \\
\hline будівництво & 180966,5 & 169705,3 & 2,7 & 11261,2 & 2,3 \\
\hline
\end{tabular}

${ }^{*}$ Сформовано автором за даними сайту Державної служби статистики України (звернення 12.02.2018)

Згідно з статистичними даними (табл. 3) у будівництві задіяні переважно малі підприємства (96,8\% від загальної чисельності), проте спостерігаються середні (3,2\%) та великі.

Таблиця 3

Кількість підприємств, які займаються будівництвом з розподілом на великі, середні, малі та мікропідприємства у 2016 р.*

\begin{tabular}{|c|c|c|c|c|c|c|c|c|}
\hline \multirow[b]{3}{*}{$\begin{array}{l}\text { Усього, } \\
\text { одиниць }\end{array}$} & \multicolumn{8}{|c|}{ У тому числі: } \\
\hline & \multicolumn{2}{|c|}{$\begin{array}{c}\text { великі } \\
\text { підприємства }\end{array}$} & \multicolumn{2}{|c|}{$\begin{array}{c}\text { середні } \\
\text { підприємства }\end{array}$} & \multicolumn{2}{|c|}{$\begin{array}{c}\text { малі } \\
\text { підприємства }\end{array}$} & \multicolumn{2}{|c|}{$\begin{array}{c}\text { 3 них } \\
\text { мікропідприємства }\end{array}$} \\
\hline & од. & $\begin{array}{c}\text { у \% до зага- } \\
\text { льної кіль- } \\
\text { кості підп- } \\
\text { риємств }\end{array}$ & од. & $\begin{array}{c}\text { у \% до зага- } \\
\text { льної кіль- } \\
\text { кості підп- } \\
\text { риємств }\end{array}$ & од. & $\begin{array}{c}\text { у \% до } \\
\text { загальної } \\
\text { кількості } \\
\text { підпри- } \\
\text { ємств }\end{array}$ & од. & $\begin{array}{c}\text { у \% до за- } \\
\text { гальної кі- } \\
\text { лькості } \\
\text { підпри- } \\
\text { ємств }\end{array}$ \\
\hline 24333 & 2 & 0,0 & 766 & 3,2 & 23565 & 96,8 & 19633 & 80,7 \\
\hline
\end{tabular}

${ }^{*}$ Сформовано автором за даними сайту Державної служби статистики України (звернення 12.02.2018)

Відповідно до статті 1 Закону України № 996-XIV [9] підприємства, що становлять суспільний інтерес, - підприємства - емітенти цінних паперів, цінні папери яких допущені до біржових торгів, банки, страховики, недержавні пенсійні фонди, інші фінансові установи (крім інших фінансових установ та недержавних пенсійних фондів, 
що належать до мікропідприємств та малих підприємств) та підприємства, які належать до великих підприємств.

Таким чином, будівельні підприємства можуть належати до підприємств, що становлять суспільний інтерес, за такими критеріями: вони є емітентами цінних паперів, цінні папери яких допущені до біржових торгів, або великими підприємствами, тобто такими, показники яких відповідно до статті 2 Закону України № 996-XIV на дату складання річної фінансової звітності за рік, що передує звітному, відповідають щонайменше двом із таких критеріїв:

- балансова вартість активів - понад 20 мільйонів євро;

- чистий дохід від реалізації продукції (товарів, робіт, послуг) понад 40 мільйонів євро;

- середня кількість працівників - понад 250 осіб.

Будівельні підприємства, які становлять суспільний інтерес, згідно з Законом України № 996-XIV умовно розподілено на такі види:

- емітенти цінних паперів, цінні папери яких допущені до біржових торгів,

- великі підприємства,

- підприємства, які не є емітентами паперів, цінні папери яких допущені до біржових торгів.

Відповідно до вказаної градації на них покладено низку обов'язків (табл. 4).

Відтак, можна констатувати такі нововведення в діяльності будівельних підприємств, якщо вони становлять суспільний інтерес: встановлено нові вимоги до головного бухгалтера, існує необхідність складання фінансової звітності за МСФЗ, ведення бухгалтерського обліку відповідно до облікової політики за МСФЗ та МСБО, обов'язок щодо оприлюднення фінансової звітності у встановлені періоди.

Таблиця 4

Законодавчо встановлені вимоги до будівельних підприємств, які становлять суспільний інтерес

\begin{tabular}{|c|c|c|c|c|}
\hline \multirow[t]{2}{*}{$\begin{array}{l}\text { № } \\
3 / n\end{array}$} & \multirow[t]{2}{*}{ Вимоги, передбачені законодавчо } & \multicolumn{3}{|c|}{$\begin{array}{c}\text { Будівельні підприємства, } \\
\text { які становлять суспільний інтерес }\end{array}$} \\
\hline & & $\begin{array}{c}\text { Емітенти цін- } \\
\text { них паперів, } \\
\text { цінні папери } \\
\text { яких допуще-- } \\
\text { ні до біржо- } \\
\text { вих торгів } \\
\end{array}$ & $\begin{array}{l}\text { Великі під- } \\
\text { приємства }\end{array}$ & $\begin{array}{l}\text { Великі підприємс- } \\
\text { тва, які не є еміте- } \\
\text { нтами паперів, } \\
\text { цінні папери яких } \\
\text { допущені до бір- } \\
\text { жових торгів }\end{array}$ \\
\hline 1 & 2 & 3 & 4 & 5 \\
\hline 1. & $\begin{array}{l}\text { Утворення бухгалтерської служби на } \\
\text { чолі з головним бухгалтером (особи, яка } \\
\text { має повну вищу економічну освіту, стаж } \\
\text { роботи у сфері фінансів, бухгалтер- } \\
\text { ського обліку та оподаткування не } \\
\text { менше }\end{array}$ & + & + & + \\
\hline
\end{tabular}


продовження табл. 4

\begin{tabular}{|c|c|c|c|c|}
\hline & $\begin{array}{l}\text { трьох років, не має непогашеної або не- } \\
\text { знятої судимості за вчинення злочину } \\
\text { проти власності та у сфері господарської } \\
\text { діяльності), до складу якої входять не } \\
\text { менше двох осіб. }\end{array}$ & & & \\
\hline 2. & $\begin{array}{l}\text { Складання фінансової звітності та кон- } \\
\text { солідованої фінансової звітності за між- } \\
\text { народними стандартами, їі подання ор- } \\
\text { ганам державної влади та іншим корис- } \\
\text { тувачам на їх вимогу, на основі таксоно- } \\
\text { мії фінансової звітності за МСФЗ в єди- } \\
\text { ному електронному форматі, визначе- } \\
\text { ному центральним органом виконавчої } \\
\text { влади, що забезпечує формування та } \\
\text { реалізує державну політику у сфері бух- } \\
\text { галтерського обліку. }\end{array}$ & + & + & + \\
\hline 3. & $\begin{array}{l}\text { Ведення бухгалтерського обліку відпо- } \\
\text { відно до облікової політики за міжнаро- } \\
\text { дними стандартами після подання пер- } \\
\text { шої фінансової звітності або консолідо- } \\
\text { ваної фінансової звітності за міжнарод- } \\
\text { ними стандартами, що визнається такою } \\
\text { у порядку, визначеному МСФЗ }\end{array}$ & + & + & + \\
\hline 4. & $\begin{array}{l}\text { Підписання фінансової звітності підп- } \\
\text { риємства керівником або уповноваже- } \\
\text { ною особою у визначеному законодав- } \\
\text { ством порядку та головним бухгалтером }\end{array}$ & + & + & + \\
\hline 5. & $\begin{array}{l}\text { Не пізніше ніж до } 30 \text { квітня року, що на- } \\
\text { стає за звітним періодом, оприлюдню- } \\
\text { вати річну фінансову звітність та річну } \\
\text { консолідовану фінансову звітність ра- } \\
\text { зом з аудиторським висновком на своїй } \\
\text { веб-сторінці та в інший спосіб у випад- } \\
\text { ках, визначених законодавством. }\end{array}$ & + & + & - \\
\hline 6. & $\begin{array}{l}\text { Не пізніше ніж до } 1 \text { червня року, що на- } \\
\text { стає за звітним періодом, оприлюдню- } \\
\text { вати річну фінансову звітність разом з } \\
\text { аудиторським висновком на своїй веб- } \\
\text { сторінці (у повному обсязі). } \\
\end{array}$ & - & - & + \\
\hline 7. & $\begin{array}{l}\text { Складання звіту про управління - доку- } \\
\text { мента, що містить фінансову та нефінан- } \\
\text { сову інформацію, яка характеризує стан } \\
\text { і перспективи розвитку підприємства та } \\
\text { розкриває основні ризики і невизначе- } \\
\text { ності його діяльності. Звіт про управлін- } \\
\text { ня подається разом з фінансовою звітні- } \\
\text { стю та консолідованою фінансовою зві- } \\
\text { тністю в порядку та строки, встановлені } \\
\text { законом. У разі подання підприємством } \\
\text { консолідованої фінансової звітності по- } \\
\text { дається консолідований звіт про управ- } \\
\text { ляння. }\end{array}$ & - & + & + \\
\hline
\end{tabular}

${ }^{*}$ Сформовано автором за даними: [9] 
Висновки і перспективи подальших розвідок. Нормативноправове забезпечення, яким визначаються концептуальні засади здійснення будівництва та обліку його фінансових результатів налічує значну кількість документів, положення яких часто суперечать одне одному, що ускладнює процес ведення обліку в цілому. У статті згруповано основні нормативно-правові документи, якими регламентовано теоретико-методичні засади здійснення будівництва та ведення обліку підприємствами, які функціонують в даному виді економічної діяльності, і при цьому виокремлено 6 рівнів управління, зокрема до рівня VI віднесено П(С)БО 18 «Будівельні контракти», що визначає концептуальні основи побудови обліку доходів і витрат будівельних підприємств, а відповідно і їх фінансових результатів, зважаючи на наявні галузеві особливості будівництва. Якщо будівельні підприємства складають звітність за МСФЗ, то в своїй діяльності вони послуговуються МСФЗ 15 «Дохід від договорів з клієнтами», 3 введенням в дію якого відмінено положення чинного впродовж багатьох років МСБО 11 «Будівельні контракти» та МСБО 18 «Дохід».

3 внесенням змін від 05.10.2017 р. до Закону України № 996-XIV з'явилося поняття підприємств, що становлять суспільний інтерес. У даному дослідженні з'ясовано, що частина будівельних підприємств $€$ підприємствами, які становлять суспільний інтерес, відтак, ідентифіковано законодавчо встановлені вимоги до ведення обліку і складання звітності таких будівельних підприємств. Подальші дослідження стосуватимуться висвітлення загальної методології обліку фінансових результатів основної діяльності будівельних підприємств і розробки рекомендацій щодо їі удосконалення.

1. Задорожний 3. В. Внутрішньогосподарський облік у будівництві : монографія. Тернопіль : Економічна думка, 2006. 336 с. 2. Крупка Я. Д., Задорожний 3. В., Мельник Р. О. Облік у будівництві : підручник. Київ : Знання, 2008. 631 с. 3. Дерій М. В. Облік і контроль грошово-розрахункових операцій в житловому будівництві : дис. ... канд. екон. наук : спец. 08.00.09. Тернопіль : THEУ, 2013. 298 с. 4. Кричун П. М. Облік та аудит незавершеного виробництва будівельних підрядних підприємств : дис. ... канд. екон. наук : 08.00.09. Київ : ДВНЗ «КНЕУ імені Вадима Гетьмана», 2012. 287 с. 5. Мужевич Н. В. Облік і аналіз витрат на утримання та експлуатацію будівельної техніки : дис. ... канд. екон. наук : 08.00.09. Тернопіль : ТНЕУ, 2014. 243 с. 6. Пославська Л. І. Облік доходів і витрат за центрами відповідальності у будівництві : дис. ... канд. екон. наук : 08.00.09. Тернопіль : ТНЕУ, 2015. 248 с. 7. Сорока Т. М. Аналіз ефективності використання виробничих ресурсів підрядних будівельних організацій України : дис. ... канд. екон. наук : 08.00.09. Тернопіль : ТНЕУ, 2016. 294 с. 8. Чижишин О. І. Облік і аналіз неопераційної діяльності підприємств : дис. ... канд. екон. наук : 08.00.09. Тернопіль, 2013. 213 с. 9. Про бухгалтерський облік та фінансову звітність в Україні : Закон України від 16.07 .1999 р. (зі змінами) : URL: http://zakon.rada.gov.ua/laws/show/996-14 (дата звернення : 01.10.2018). 


\section{REFERENCES :}

1. Zadorozhnyi Z. V. Vnutrishnohospodarskyi oblik u budivnytstvi : monohrafiia. Ternopil : Ekonomichna dumka, 2006. 336 s. 2. Krupka Ya. D., Zadorozhnyi Z. V., Melnyk R. O. Oblik u budivnytstvi : pidruchnyk. Kyiv : Znannia, 2008. 631 s. 3. Derii M. V. Oblik i kontrol hroshovo-rozrakhunkovykh operatsii v zhytlovomu budivnytstvi : dys. ... kand. ekon. nauk : spets. 08.00.09. Ternopil : TNEU, 2013. 298 s. 4. Krychun P. M. Oblik ta audyt nezavershenoho vyrobnytstva budivelnykh pidriadnykh pidpryiemstv : dys. ... kand. ekon. nauk: 08.00.09. Kyiv : DVNZ «KNEU imeni Vadyma Hetmana», 2012. $287 \mathrm{~s}$. 5. Muzhevych N. V. Oblik i analiz vytrat na utrymannia ta ekspluatatsiiu budivelnoi tekhniky: dys. ... kand. ekon. nauk : 08.00.09. Ternopil : TNEU, 2014. 243 s. 6. Poslavska L. I. Oblik dokhodiv i vytrat za tsentramy vidpovidalnosti u budi-vnytstvi : dys. ... kand. ekon. nauk : 08.00.09. Ternopil : TNEU, 2015. 248 s. 7. Soroka T. M. Analiz efektyvnosti vykorystannia vyrobnychykh resursiv pidriadnykh budivelnykh orhanizatsii Ukrainy : dys. ... kand. ekon. nauk : 08.00.09. Ternopil : TNEU, 2016. 294 s. 8. Chyzhyshyn 0. I. Oblik i analiz neoperatsiinoi diialnosti pidpryiemstv : dys. ... kand. ekon. nauk : 08.00.09. Ternopil, 2013. 213 s. 9. Pro bukhhalterskyi oblik ta finansovu zvitnist $v$ Ukraini : Zakon Ukrainy vid 16.07.1999 r. (zi zminamy) : URL: http://zakon.rada.gov.ua/laws/show/996-14 (data zvernennia : 01.10.2018).

Рецензент: д.е.н., доцент Осадча О. О. (НУВГП)

Pavelko 0. V., Candidate of Economics (Ph.D.), Associated Professor (National University of Water and Environmental Engineering, Rivne)

\section{CONCEPTUAL BASES OF FINANCIAL RESULTS ACCOUNTUNG OF CONSTRUCTION ENTERPRISES}

The article examines the levels of management of financial results in construction. They are considered from the position of micro and macroeconomics. The analysis of the number of enterprises engaged in construction with distribution to large, medium, small and microenterprises is conducted.

There are six levels of legal regulation that identify the basic principles of construction and accounting of its financial results in Ukraine, in particular, the level VI is assigned to National standard of accounting 18 «Construction Contracts», which defines the conceptual framework for the accounting of income and expenses of construction enterprises, and, accordingly, their financial results, taking into account the existing industry features of construction. If construction companies compile reports according to International accounting standards, they use IFRS 15 «Revenue from Contracts with 
Customers» in their activities. IAS 11 "Construction Contracts" and IAS 18 "Revenue" which have been used for many years have expired.

Regulatory and Legal Support, which defines the conceptual framework for the construction and accounting of its financial results, includes a large number of documents, the provisions of which often contradict each other, which complicates the process of accounting as a whole. The article summarizes the main legal documents regulating the theoretical and methodological principles of construction and accounting of enterprises that function in this type of economic activity, and at the same time six levels of management are singled out.

With the accepting of the changes of 05.10.2017 to the Law of Ukraine No. 996-XIV the concept of enterprises of public interest appeared. In this study it was found that some construction companies are enterprises of public interest; therefore, the legally stipulated requirements for accounting and reporting of such construction enterprises are identified.

Keywords: construction, accounting, construction company, methodology of accounting, type of economic activity, financial results, reporting, construction products.

Павелко О. В., к.э.н., доцент (Национальный университет водного хозяйства и природопользования, г. Ровно)

КОНЦЕПТУАЛЬНЫЕ ОСНОВЫ ПОСТРОЕНИЯ УЧЕТА ФИНАНСОВЫХ РЕЗУЛЬТАТОВ СТРОИТЕЛЬНЫХ КОМПАНИЙ

В статье исследованы уровни управления финансовыми результатами в строительстве. Они выделены с позиции микро- и макроэкономики. Систематизированы основные нормативно-правовые документы, регулирующие базовые принципы осуществления строительства и учета его финансовых результатов. Проанализировано количество предприятий, которые занимаются строительством с распределением на большие, средние, малые и микропредприятия. Определены законодательно установленные требования к строительным предприятиям, представляющим общественный интерес.

Ключевые слова: строительство, учет, строительное предприятие, методология учета, вид экономической деятельности, финансовые результаты, отчетность, строительная продукция. 